\title{
Amateur art as a scientific problem
}

\author{
G. V. Zub \\ Kharkiv National Pedagogical University named G. S. Skovoroda, Kharkiv, Ukraine \\ Corresponding author. E-mail: gregozby@gmail.com
}

Paper received 27.04.18; Accepted for publication 05.05.18.

\section{https://doi.org/10.31174/SEND-HS2018-168VI27-01}

\begin{abstract}
In the article, based on the analysis of scientific researches, the content of the concept "amateur art" is revealed, its relationship with the notion "artistic amateur", with professional art and folklore is explored. It is shown that amateur art functions in the field of amateur; the division of the sphere of art into a professional and amateur is connected with the process of division of labor; amateur art developed in parallel with professional art and folklore; it belongs to folk artistic creativity. It is proved that modern fashion on the musical repertoire of amateur groups determines the volume of the musical market of show business; a characteristic feature of modern pop amateur art is the joint creative activity of amateurs and professionals.

Keywords: amateur art, head of the instrumental amateur group.
\end{abstract}

Introduction. The sociocultural transformations taking place in Ukrainian society, the integration of the state into the European community, lead to the reform of the national higher education, in particular the professional training of future music teachers in pedagogical educational institutions. According to this, the problem of training future specialists in the field of pop performance, management of instrumental pop amateur groups is relevant. This direction of professional examination corresponds to one of the areas of professional activity of a specialist in musical art.

A brief review of publications on the thesis. The analysis of scientific works gives the grounds for the conclusion about the significant contribution of scientists to the study of various aspects of the problem. The conceptual foundations of the professional training of future teachers of musical art in the system of higher pedagogical education (V. Draipika, O. Myhailychenko, O. Oleksyuk, G. Padalka, O. Rostovsky, O. Schoslokova and others) are developed. The content of professional study of orchestral conductors in higher educational institutions of culture and arts are found (L. Ginzburg, R. Davydyan, V. Deinega, M. Kanershtein, M. Kolesa, Yu. Loshkov, G. Makarenko, V. Tekidach, I. Polskaya, Y. Sverlyuk, etc.). Some researches are devoted to problems of pedagogical management by musical instrumental groups: folk instrumental ensemble - A. Bulgarian; children's wind orchestra team - O. Nezhensky, Ya. Sverlyuk; Student musical group - V. Lebedev, I. Marinin, L. Pankov, T. Plyachenko; amateur artistic collective O. Kargin, N. Slobodyanyk, M. Sokolovsky, F. Solomonyk, V. Chabanny. However, the preparation of future masters of musical art for work with pop instrumental amateur groups was not the subject of scientific research.

The goal of the article - is to clarify the scientific content of the concept of "amateur art", to outline its boundaries, to comprehend its essence in order to actualize the problems of preparing future masters of musical art for leadership amateur instrumental groups.

Materials and methods. The following methods were used: analysis, synthesis, comparison, definition, identification of semantic blocks and ideas, generalization, modeling for the definition of initial theoretical and methodological positions.
Results and discussion. In pedagogical, sociopsychological studies significant material on the activities of amateur teams is accumulated. However, the scientific analysis of many issues on amateur art faces insufficient development of the fundamental and theoretical aspects of this phenomenon.

Consider the scientific content of the concept of "amateur art," begining from the etymological analysis of the word "amateur". I. Sreznevsky, dates the words "amateur - amateur" back to the XI century, referring to the ancient monument "Pandect Antioch on 19th century 17. Voskresenskago Novoierusalimskago mon. "(Monastery) and considers them in the sense of "love, to be inclined" to anything [12, p. 33]. An Explanatory Dictionary of the Ukrainian language defines the word "amateur" as "one who is willing to do something, loves in something; amateur (at 1 meaning). / The one who deals with something not as a professional; amateur (at 2 meaning)" [3, p.38].

In the question of the time of the emergence of artistic amateurism, we rely on the research of well-known scholars F. Prokofiev, E. Smirnova, and Y. Kulikov, who argue that, since the era of social division of labor, artistic life has been divided into artistic production and artistic consumption, and artistic activity on professional and unprofessional, that is amateur. We share the point of view of scientists that from this period the amateur art begins. Isolation of space for the development of personality, its individuality, free creative activity is the historical achievement of civilization development of culture. Y. Kulikov believes that amateur art is a "social and cultural correlation of professional art. Professionalism and amateurism, complementing each other appropriately, form two poles of limited appropriation of activity based on the social division of labor" [2, p.59].

Scientific research in the field of philosophy, art studies, pedagogy, sociology, and psychology is devoted to the theory and history of amateur art. Problems of amateur art in the Ukrainian art studies were not relevant for a long time; this direction was studied in separate works.

Only in the 20 years of the 20th century in the history of Soviet art, there were works on amateur art. At this time a mighty social factor in aesthetic transformation of life was seen in the amateurish activities of the working class. Amateur creativity was carefully analyzed by wellknown art historians (A. Bakushinsky, A. Piotrovsky, 
B. Asafiev, and etc). B. Asafiyev, expressing his opinion on the national principle in art, offered to separate artistic amateur from folklore [1, c. 122]. This view is quite appropriate for understanding the amateur art and its boundaries.

At the same time there were the first organized forms of amateurism. Normative documents of Soviet power contributed to the active creation of a large number of amateur circles, various ensembles (duets, trios, quartets), orchestras of folk instruments (accordion orchestras), etc.

Gradually, the identification of amateur artistic creativity with activities that are not limited by the social division of labor, led to the abandonment of the term "amateurism". The artistic amateurism of the proletariat since the middle of the 20th century has been consolidated by the name "artistic amateur". It was intended not only to emphasize social homogeneity and the mass of proletarian amateurism, but also its connection with revolutionary events and Marxist ideology.

The concept of "artistic amateurism" and "artistic amateur", their boundaries are ambiguously interpreted in current scientific research. Researchers consider the interconnections of these concepts to be different, but do not consider them identical. N. Mikhailova notes that "... under the apparent clarity of the concepts of" artistic amateur "and" amateur art, "they do not belong to those which are unambiguously understood by all in practice and do not have clear links with the terminological traditions of a particular science or sciences " [5, p. 36].

In defining the concept of "artistic amateur", some authors limit it to the process of artistic creativity, others deduce beyond the boundaries of artistic culture. A. Myhailyk states that "artistic amateur art is not only an occupation of people by art. It is also an activity aimed at raising the general cultural and artistic and aesthetic level of education of the people; the form of the rest of people, the filling of free time, communication, support emotional and moral optimism, as an individual, and entire groups and groups; finally, the form of manifestation of the festive mood of people" [4, p. 134-135]. In this definition, there is the interpenetration of certain attributes of amateur performances with some specific and non-specific functions of amateur art, which does not allow to obtain a coherent idea of artistic amateur performance.

Reasonable approaches to the definition of the concept of "artistic amateur" are found in the works of T. Baklanova, A. Kargin, N. Mihailova, E. Smirnova and others. They are contain an analysis of the relation in this concept of processes of artistic production and artistic consumption, which are realized in leisure activities. On the basis of the above, it can be argued that artistic amateur activities are not limited to amateur art as a sphere of artistic production, but also includes various types of artistic activities.

The theoretical comprehension of the concept of "artistic amateur" as a social and artistic phenomenon begins from the 60-ies of 20th century. The philosophers (A. Vartanov, A. Yegorov, P. Ryumin, etc.) and art critics (V. Vasilenko, L. Yemelianov, A. Sokhor, and others) address the analysis of its problems. From the philosophical point of view, the category of "amateur" is defined as an internally deterministic activity, that is, an activity that is not imposed externally, but determined by the internal needs, interests, desires of the individual. Thus, amateur action is a means of unregulated manifestation of person- ality, a condition of human development. It is an objective and one of the highest values for both man and society as a whole.

Convincing is the point of view of F. Prokofiev and Y. Sokolovsky, who relate the emergence of amateur with the formation of the Soviet state, considering it to be the product of the socialist system [11, p. 89]. The main result of the study of amateur issues during this period was the recognition of its relatively independent component of culture, which differs from professional art, and from traditional folk art.

The study of whole content of concept "artistic amateur activities" and tangible gaps in the theory of amateur art, compel researchers, in particular, A. Kargin, Y. Kulikov, A. Mazaev, to address the issues of the essence of artistic amateurism, its boundaries, aesthetic originality of mass forms. The closest approach to their solution is Y. Kulikov, who expresses the opinion that amateur art is not localized by the "third space of art" and has the right to be seriously investigated by scholars.

The collective works of ukrainian scholars played a positive role in the creation of new concepts of amateur art. V. Noyiychuk suggests his understanding of this phenomenon, which considers that "it defines itself not formally, but meaningfully - as a sociocultural phenomenon of free choice of activity" [8, p. 317]. Some interest for us is also the study of Y. Petrov about the philosophical and aesthetic aspects of the development of an amateur subject, from the point of view of which he considers artistic amateur as a manifestation of amateur in the art [9].

We that amateur art functions in the field of amateur (in the broad sense of the word) and do not agree with the authors, who consider artistic amateur phenomena to be narrower than amateur performances, reduce it to the level of "home" forms of amateur performance. We believed that such a view is generated by the idealization of artistic amateurism, which took place under socialism.

An important direction in the study of the essence of amateur art is its relationship with professional art and folklore.

It should be noted that during the 20th century amateur art developed alongside professional (academic) forms of performing and traditional (folklore). The birth of amateur instrumental performances, the flowering of various ensemble-orchestral forms of its functioning in Ukraine was caused by the creativity of talented instrumentalists and its substantial support by state institutions. Through their active organizational and artistic and creative activities they were able to raise amateur art to a new level of performance and to bring it closer to a professional.

Research of amateur folk instrumental performance of Ukraine, its forms, priority trends and trends are reflected in the scientific researches of well-known domestic and foreign scientists R. Bezugloy, A. Gumenyuk, V. Gutsal, P. Ivanov, O. Ilchenko, O. Kargina, V. Lapchenka, Y. Loshkova, Y. Yutsevich, Y. Bezpyatova and etc.

It could be concluded that the historiographical analysis of the concept of "amateur art" suggests that the division of art into professional and amateur, which is associated with the process of division of labor. Amateur art developed in parallel with the professional, on the one hand, and folklore - on the other. It belongs to folk art, where, as in folklore, the subject of artistic activity is not a professional, but a person engaged in creativity in his free time and does not receive material rewards for it. 
Unlike folklore, amateur art is an unconventional sociocultural form of folk art.

The conclusion that artistic amateurism, unlike professional art, has its main purpose of educating amateurs, and not the public, has led to increased attention to its pedagogical problems. Among the significant number of works in this direction, one can identify the monographs of Y. Sokolovsky and F. Solomonik, in which the theoretical questions of amateur art are considered.

In pedagogical studies of I. Arkhangelskii, L. Braginsky, D. Braslavsky, V. Volkov, A. Korotyeev, V. Kuznetsov, E. Mishchuk, A. Nizhynskyi, B. Penchuk, amateur performances are most often considered in the context of socio-pedagogical problems. The close connection between the development of amateur art and education in Ukraine has been studied in the following areas: extracurricular education of adults (Sunday schools); activities of public cultural and educational organizations in raising the general culture; preparing future music teachers to lead pop groups in extracurricular work.

Modern fashion on the musical repertoire of amateur groups determines the volume of the musical market of show business, which is growing sharply. This process is relevant for research in the field of art pedagogy. In the works of such scholars as B. Brilin, Y. Stepnyk, O. Sapozhnik, Y. Cherenkov, O. Shishov, G. Shostak and etc. It is noted that the prevailing need of present youth is pop music. It should be noted that older people have an interest in listening and performing jazz, pop music of various styles.

So far, the problem of improving future specialists in the field of musical variety art is considered to be researched a little in musical pedagogy. Some issues are highlighted: the issues of amateur performances in various variety groups (A. Koroteev, V. Kuznetsov, V. Matuk, E. Mishchuk, B. Penchuk), the question of pop art in the plane of its multi-genre and style (A. Batashev, V. Kuznetsov, O. Sapozhnik, G. Shostak, E. Fedorov), the issues of development of creative personality and personality in the conditions of pop art (N. Drozhzhina, D. Mechik), the question of using "Technical Ways of Learning" in musical-pop preparation (O. Polyakova), aspects of the culture of personality in the context of the influence of music mass genres (G. Shostak,), pedagogical problems of the future specialist training in musical variety performances (T. Vasiliev, L. Norinsk, Y. Stepniak). As for the preparation of the leaders of amateur pop groups, some aspects of this problem were developed in master's theses: M. Filipchuk, D. Babich. However, the preparation of future masters of musical art for work with pop instrumental amateur groups has not been the subject of scientific research.

However, this direction is relevant, since the pedagogical role of both the music teacher and the head of the amateur instrumental group is of special social significance. The teacher, the manager who has the performance variety skills, or competent in the field of music, first of all directs his activities to the formation of musical tastes of adolescents on examples of high-art works within this genre. He has to perform variety work not only himself on a high-quality, highly artistic level, but also to be able to improve the performance of students, orchestras, ensembles, to be able to develop their hearing and art of intonation. In addition, as recommended by O. Polyakov, he should stimulate their creative activity, the initiative in the search for the interpretation of works performed, independence, the need to communicate with music of other genres (folk and classical) [10, p. 75].

A characteristic feature of contemporary amateur instrumental art is the joint creative activity of amateurs and professionals, which contributes to the implementation of complex virtuoso works, expands the concert repertoire of the groups. Professional artists perform the main parties, and amateur singers relatively simple parties; at the same time, the team carries out important educational activity, has the ability to perform musical works on a high professional level.

It should be noted that a significant part of the repertoire of contemporary amateur groups is their appeal to the variety, its best samples. Such scholars as G. Padalka, O. Schlokokova consider it expedient to use contemporary musical specimens of high quality, which have aesthetic potential in school curricula.

It should be noted that the field of musical variety is a rather diverse, multi-style and multi-genre phenomenon, which has many positive characteristics, which knowledge contributes to solving actual generalpedagogical, general-aesthetic and special tasks: qualitative transformation of musical tastes and needs of both students and future specialists, preparing them for the perception of more complex, deeper and more serious music, the disclosure of its creative-improvisational potential. At the same time mastering pop music art not only complements and extends the content of musical education, but also contributes to the revitalization and revival of the learning process [1:3].

In modern Ukraine, according to the Decree of the President of Ukraine dated 23.10.99 No. 1387/99 "On All-Ukrainian Review of Folk Art" [9], reviews of amateur groups take place in the regions, and then the best teams perform in Kyiv at the National Palace of Culture and Arts "Ukraine" and they are entitled "Reporting concerts of the regions of Ukraine ". According to the Regulation approved by the Decree of the Ministry of Culture and Arts of Ukraine dated 06/26/1999 No. 415 and its amendments (Order of the Ministry of Culture of Ukraine of 11.10.2013 No. 968), the permanent amateur groups are awarded the title "folk (exemplary) amateur group (studio) "For the active creative activity in preserving, developing and promoting the culture of the Ukrainian people, both in Ukraine and abroad, high artistic level and performing skills, active educational and educational work among the members of the collective, participation in the organ the idea of leisure activities of the population [provisions]. This indicates a significant state attention to amateur creativity.

Festivals of oven and pop music are regularly held in Ukraine. For example: Melitopol festival of oven and pop music "Tavriyskiye antimoni" (19-20.05.2017, where about 700 participants tack place 30 orchestras from 10 cities of Ukraine competed), the festival "Horizons of jazz" in Kryvyi Rih (more than 25 groups, among them ensembles, orchestras, big bands, quartets, trio, etc.), the International Festival of jazz music in Odessa (more than 30 collectives), etc.

Nowadays, the education of variety programs is received at many colleges of culture and arts, music schools, music academies and universities in specialization "Music Art". These are: School of Culture and Arts named after M. D. Leontovich (Vinnitsa), Musical Col- 
lege named after M. I. Glinka (Dnipropetrovsk ), Music College (Kryvyi Rih ), Music College (Mariupol), State Music College of D. V. Sichynsky (Ivano-Frankivsk), National Music Academy of Ukraine named after P. I. Tchaikovsky, State College of Pop and Circus Arts (Kyiv ), State Institute of Culture and Arts (Luhansk), State Musical Academy named after M. V. Lysenko (Lviv), State Musical Academy of A. V. Nezhdanova (Odessa), State Humanitarian University (Rivne), Department of Music Art of Pop and Jazz at Kharkiv State University of Arts named after I. P. Kotlyarevsky (conservatory), created by Academician Litvinov and etc.

At the same time, comparing the number of graduates from conservatories, cultural institutes, musical colleges, cultural and educational colleges, where the groups of instrumental group leaders were numbered 20-25 students in the second half of the 20th century, makes it possible to point out that today such the figure is reduced to $8-10$ people. The result was a reduction in the number of such specialists training, which affects the number of managers of amateur instrumental groups and the quality of their performance.
Also, it is necessary to pay attention to the fact that there are no disciplines such as "Variety Music", "Pop Music Styles", "Variety Instrumental Amateur Art", etc., in the curricula for the training of future music teachers, although in the program "Music Art" for the 5th form we find topics devoted to the study of amateur musical art (Theme No 10), etc.

Conclusions. The lack of appropriate training of music teachers does not facilitate the adaptation of future professionals to the socio-cultural conditions in which they should work, does not approach to the children's listening audience, does not provide the opportunity to acquire the necessary knowledge, work out repertoire and gain experience with variety instrumental amateur groups, which, undoubtedly, have their own specifics. The training of masters gives an opportunity to expand the range of disciplines for the training of masters of musical art to work with amateur instrumental pop groups, to give them the opportunity to gain competence in the field of the leader of the modern variety amateur instrumental collective.
1. Asafiev B. V. (1987) O narodnoy muzyike [About the folk music]. Moscow: «Muzyika». Moscow (in Russian)

2. Kulikov Yu. N. (1984) Kulturologicheskiy aspekt teorii samodeyatelnogo iskusstva [Culturological aspect of the theory of amateur art]. Narodnoe tvorchestvo i sovremennost. Voprosyi metodologii izucheniya - Folk art and modernity: Questions of study methodology, p. 34-71. (in Russian)

3. Melnychuk O. S. \& Bilodid I. K., Kolomiiets V. T., Tkachenko O. B. (Eds) (1982) Etymolohichnyi slovnyk ukrainskoi movy [The etymological dictionary of the Ukrainian language] (Vol 1). Kyev: Naukova dumka (in Ukrainian).

4. Mihaylik A. G. (1977) Tendentsii razvitiya hudozhestvennoy samodeyatelnosti na sovremennom etape: avtoref [Tendencies of the development of amateur art at the present stage]. Extended abstract of condidate's thesis. Leningrad: Leningr state Institute of Culture for them. NK Krupskaya (in Russian)

5. Mihaylova N. G. (1984) Samodeyatelnoe hudozhestvennoe tvorchestvo: puti issledovaniya i perspektivyi razvitiya [Amateur artistic creativity: ways of research and development prospects]. Nekotoryie tendentsii kulturno-prosvetitelnoy deyatelnosti - Some tendencies of cultural and educational activity, Is. 131 , p. 35-55.

6. Nakaz «Pro polozhennia pro narodnyi (zrazkovyi) amatorskyi kolektyv (studiiu) zakladiv kultury» № 415 vid 23. 06. 99 [Order on the Regulations on the national (exemplary) amateur group (studio) of cultural institutions № 415 from 23. 06. 99]. (1999, June 23). (a.d.) zakon.rada.gov.ua. Retrieved from http: zakon.rada.gov.ua (in Ukrainian)

7. Nakaz Prezydenta Ukrainy «Pro Vseukrainskyi ohliad narodnoi tvorchosti» vid 23.10.99 № 1387/99 [About AllUkrainian review of folk art from 23.10.99 № 1387/99].

\section{CIS}

(1999, October 23). (a.d.) zakon.rada.gov.ua. Retrieved from http: zakon.rada.gov.ua (in Ukrainian)

8. Noviichuk V. I. (1996) Narodno-profesionalni zviazky ta tendentsii rozvytku folklornykh form tvorchosti [Peopleprofessional connections and tendencies of development of folk forms of creativity]. Kyev: Lybid (in Ukrainian)

9. Petrov Yu. V. (1993) Filosofsko-estetychni aspekty rozvytku samodiialnoho subiekta: problemy teorii [Philosophical and aesthetic aspects of the development of an amateur subject: problems of theory]. Extended abstract of Doctor's thesis. Kyev: National University named after T. G. Shevchenko (in Russian)

10. Polyakova O. I. (2003) Teoretiko-metodicheskie aspektyi ispolzovaniya TSO $\mathrm{v}$ protsesse obucheniya peniyu podrostkov [Theoretical and methodical aspects of the use of TSS in the process of teaching the singing of adolescents]. Extended abstract of condidate's thesis. Moscow: Moscow state humanist Un-t them. M. A. Sholokhov (in Russian)

11. Prokofev F. I. (1978) Hudozhestvennoe tvorchestvo mass v usloviyah razvitogo sotsializma [The artistic creativity of the masses in conditions of developed socialism]. Kiev: Vischa shkola (in Ukrainian).

12. Sreznevskiy I. I. (1893) Materialyi dlya slovarya drevnerusskogo yazyika po pismennyim pamyatnikam [Materials for the Dictionary of the Old Russian language from written monuments] (Vol 1). - SPb. : Otd-nie rus. yaz. i slovesn (in Russian).

13. Vasileva T. A. (2007) Formirovanie osnov estradnogo ispolnitelstva u uchaschihsya-akkordeonistov na nachalnom etape obucheniya [Formation of the basics of variety performance in accordion students at the initial stage of training]. Extended abstract of condidate's thesis. Moscow: Moscow state humanist Un-t them. M. A. Sholokhov (in Russian).

\section{Аматорское искусство как научная проблема}

\section{Г. В. Зуб}

Аннотация. В статье на основе анализа научных исследований раскрыто содержание понятия «аматорское искусство», исследованы его взаимоотношения с понятием «художественная самодеятельность», с профессиональным искусством и фольклором. Показано, что аматорское искусство функционирует в сфере самодеятельного; разделение сферы искусства на профессиональное и самодеятельное связано с процессом разделения труда; аматорское искусство развивалось параллельно с профессиональным искусством и фольклором; оно относится к народному художественному творчеству. Доказано, что современная мода на музыкальный репертуар аматорских коллективов определяет объем музыкального рынка шоу-бизнеса; характерной чертой современного эстрадного аматорского инструментально искусства является совместная творческая деятельность аматоров и профессионалов.

Ключевые слова: аматорское искусство, руководитель инструментального аматорского коллектива. 